\title{
STUDENTS' PERCEPTION OF EXTENSIVE READING ACTIVITY THROUGH READING LOG
}

\author{
Gabriella ${ }^{3}$; Veronica L. Diptoadi ${ }^{4}$
}

\begin{abstract}
As prospective English teachers, the students of the English department are expected to have sufficient English proficiency especially reading skills since most of the resources in the learning process are printed in English. Responding to the previous demand, the English Department provides a supplementary activity for developing the students' reading skills. Hence, the focus of this study is on investigating how the students perceived the role of extensive reading activity in Reading A course in motivating them to read more in order to improve their reading skills as well as to enhance other skills and components, such as writing, speaking, and vocabulary. The questionnaire was answered by 29 students to find out their perception on extensive reading activity in Reading A course during the academic year of 2017/2018. In addition to the questionnaire, the lecturer of the course was also interviewed to confirm the students' responses. After the data analysis, it was discovered that the students' perception on extensive reading activity was positive.
\end{abstract}

Keywords : Reading, Extensive Reading, Reading Log, Perception

\section{Introduction}

Nowadays, people are expected to acquire English since it is one of the most important languages in the world. When the demand increases, many high school graduates enter English Education Program which offers

\footnotetext{
${ }^{3}$ English Education Study Program Faculty of Teacher Training and Education Widya Mandala Catholic University Surabaya

${ }^{4}$ Lecturer English Education Study Program Faculty of Teacher Training and Education Widya Mandala Catholic University Surabaya
} 
a promising opportunity to become prospective English teachers. As students in the English Department, all of them are supposed to have sufficient English proficiency especially reading skills. However, most students are still struggling with comprehending English texts. As a result, the English Department promotes extensive reading activity to improve the students' reading skills. Regarding the supplementary activity, this study was conducted to figure out how the students perceived the activity during Reading A course in the academic year of 2017/2018. Besides, the students were asked to reading novels or compilations or short stories of their own choices extensively, they had to make reading logs for every chapter they had read. The results of this study are expected to offer another alternative in teaching reading in EFL classrooms and to become a reference for teachers and lecturers who have implemented extensive reading to evaluate their practices. Not only teachers and lecturers, other researchers who conduct studies with similar topic can use this study as a reference to support their own researches.

\section{Literature Review}

Reading is crucial in human life as it enables people to get information and to communicate with one another. In fact, reading is a form of 'functional autonomy' in human life. In other words, most people simply cannot avoid reading even though they intend to gain any information (Gibson \& Levin, 1975). Basically, reading is a cognitive process which compares and combines schemata or background knowledge and new information (Mikulecky, 2008). There are two kinds of reading processes: bottom-up and top-down. Mikulecky (2008) quotes the idea of those reading processes from Kintsch and Van Dijk 1978; Rumelhart and Ortony 1977; Winogard 1977; and Rumelhart 1980. Bottom-up is a reading process in which readers focus more on the information from the texts they read. On the other, top-down is the process where readers rely on their schemata rather than the texts. Furthermore, Gibson and Levin (1975) state that there 
are some purposes of reading, such as to gain information either in daily life or in academic environment and to get involved in written communication. It is apparent that reading skills are needed by the students of the English Department to obtain academic information as well as to master their field as future English teachers. In most cases, the students can get discouraged easily when they read academic materials. If they start getting discouraged, they will get less exposure to English texts. At last, their reading skills are stunted due to lack of practice.Furthermore, Hunt (2014) mentions other problems that hamper the students' reading abilities. He includes low motivation, lack of interest, and little exposure.

One alternative which motivates the students to read more in order to get enough exposure to English texts is extensive reading. Ghanbari and Marzban (2013) define extensive reading as a reading activity in which the readers deal with a considerable quantity of texts. Therefore, their confidence and reading fluency are needed. Extensive reading can also be considered as reading for pleasure since the readers are able to choose the books based on their interests (Mikulecky, 2008). When the readers have the opportunity to choose their own books, their reading skills can develop easier because they see the reading activity as meaningful and enjoyable (Bamford \& Day, 1997). In addition, Hofer (2011) explains about theory of motivation in the classrooms. She states that there are two kinds of motivation that the students have: intrinsic and extrinsic motivation. Intrinsic motivation is a motivation which appears when a student has the urge to do activity due to the value of the activity itself. On the other hand, extrinsic motivation works when there are other influences outside such as reward. By reading extensively, the students' intrinsic and extrinsic motivations are expected to increase (Hunt, 2014). When the lecturer assigns the students to do extensive reading and make reading logs, they will do the assignments as well as possible in order to get good scores which boost their extrinsic motivation. Sequentially, extensive reading plays an important role in sparking the students' curiosity toward the content of the 
books they have chosen. In other words, extensive reading also increases the students' intrinsic motivation. Motivation is closely related to choice, effort, and persistence (Hofer, 2011). To get motivated, the students should have the sense of autonomy and self-determination in the form of the opportunity to choose. In the extensive reading activity, the students are allowed to decide which books they are going to read for the whole semester. When their autonomy and self-determination are fulfilled, the students will show their effort as well as their perseverance in coping with any problems during the activity. Not only motivating the students to read more, Ghanbari and Marzban (2013) also point out some other advantages of extensive reading including enriching the students' vocabulary, enhancing their writing skills, increasing the students' confidence, and crystallizing the students' knowledge.

As explained before, extensive reading is aimed to improve the students' reading skills so that they can acquire sufficient reading comprehension. However, lecturers or teachers are not able to directly assess the students' reading comprehension since reading is not an observable process according to Pollitt and Taylor in 2008. Therefore, follow-up activities are required so that the lecturers or teachers are able to supervise the students' tangible progress. One of the follow-ups that can be combined with extensive reading is making reading logs. Mikeladze (2014) agreed that by asking the students to make reading logs after reading extensively, the lecturers and teachers can monitor the level of the students' reading abilities. In addition to reading logs, she also suggests conducting oral examination. Both reading logs and oral examination consolidate the students' comprehension because they are not able to simply copy and paste what they have read. Instead, they are demanded to understand the books in order to present it in the oral examination. Besides to improve the students' reading comprehension and to monitor their progress, reading logs can also be used to track the students' personal opinion and attitudes toward the content of the books (Lyutaya, 2011). Neufeld (1975) adds that 
reading logs encourages the students to make their individual goals and reports of their progress. Another advantage of making reading logs that it can help the students to enhance their writing skills since reading and writing are connected to each other (El-Hindi, 1997).

Since this study is about the students' perception on extensive reading, the concept of perception should be clearly explained. Perception is a result of the cognitive process which occurs when a human interacts with the world around him. In fact, it starts from the human's senses which lead him to the emotional and behavioral reaction toward what he has sensed (UK Essays, 2018). Similar to reading process, perception has two types: bottom-up and top-down. Perception using the bottom-up process starts the process from the lowest sensory data to the most complex cognition while the one with the top-down process uses prior knowledge to understand lower features of higher thinking contents. In short, the key of bottom-up process is based on the senses which perceive the reality while interpretation plays the most important role in top-down process as previous experiences are needed in order to understand the reality. Adhered to the previous ideas of perception, it is presumed that the subjects who got involved in the extensive reading perceived the activity by using bottomup process while they were conducting the activity as they relied on their sensory data to learn the activity. When they express their perception through either questionnaire or interview, they picture the activity they have experienced using top-down process since they associate their opinions with their prior knowledge relating to the activity in the past.

\section{Research Methodology}

This study is considered as a descriptive research using survey design. Consequently, questionnaire and interview questions were constructed as the instruments of this study besides the researcher herself. The questionnaire consisted of 26 items of closed-ended questions using Likert Scale and five items of open-ended questions. In the closed-ended 
section, the items were divided into four categories: 'General Attitudes to Extensive Reading', 'Exposure to English Texts', 'Motivation', and 'Impact to Other Skills and Components of English'. All items in the questionnaire and interview were arranged based on the theories in Literature Review and adapted from similar researches and the real situation during the activity. As indicated in the introduction that the purpose of this study was to find out the students' perception on extensive reading, the main subjects of this research were 29 students who attended Reading A course in the academic year of 2017/2018. In order to confirm their responses, the lecturer of the course was interviewed.

The process of data collection was started by designing the questions for questionnaire and interview. After they were completed, those instruments were consulted to the researcher advisor to determine whether it was necessary to revise or not. If there was nothing to revise, try-out was conducted to eight students who also attended Reading A course in the academic year of 2017/2018. The evaluation of the questionnaire was obtained as a result of the try-out. When the questionnaire had been revised and approved by the advisor, it was distributed among the students. Then, the interview with the lecturer was carried out after all the questionnaire was completed. After the process of data collection was done, the analysis of the data was conducted. The process was initiated by transferring the amount of the students' responses into percentage and classifying their answers in the open-ended section, and the interview was transcribed. The questionnaire results were compared with the lecturer's responses in the interview. Interpretation was made based on the results of the questionnaire and interview. Then, it was associated with the theories in the Literature Review. 
Table 1. The Sum of the Students' Perception on Extensive Reading and Reading Logs

\begin{tabular}{|l|c|c|c|c|c|}
\hline & $\begin{array}{c}\text { Strongly } \\
\text { Disagree }\end{array}$ & Disagree & Agree & $\begin{array}{c}\text { Strongly } \\
\text { Agree }\end{array}$ & Total \\
\hline $\begin{array}{l}\text { Number of } \\
\text { Responses } \\
(26 \text { Items) }\end{array}$ & 18 & 129 & 404 & 203 & 754 \\
\hline Percentage & $2 \%$ & $17 \%$ & $54 \%$ & $27 \%$ & $100 \%$ \\
\hline & \multicolumn{2}{|c|}{ Negative } & \multicolumn{2}{|c|}{ Positive } & Total \\
\hline $\begin{array}{l}\text { Number of } \\
\text { Responses } \\
\text { (26 Items) }\end{array}$ & \multicolumn{2}{|c|}{147} & \multicolumn{2}{|c|}{607} & 754 \\
\hline Percentage & \multicolumn{2}{|c|}{$19 \%$} & \multicolumn{2}{|c|}{$81 \%$} & $100 \%$ \\
\hline
\end{tabular}

According to the students' responses in the first section of the questionnaire, most of the students showed their positive perception on extensive reading activity in Reading A course. In other words, the students agreed that extensive reading activity enabled them to experience reading meaningful and enjoyable books as indicated in the theory of extensive reading by Bamford and Day (1997). Reading texts became meaningful and enjoyable for the students since they had the opportunity to choose the books based on their interests and ability. As the students discovered that the books they read offered the sense of meaningfulness and enjoyment, they admitted that they got absorbed in their books. Consequently, they gained more exposure toward the English texts. In enhancing the students' reading skills, exposure to the texts with target language is crucial as proposed by Rankin (2005) because exposure helps the students to improve their reading comprehension. Hunt (2014) even mentions some problems 
the students usually deal with in reading. One of the most frequent problems is lack of exposure to English texts. Responding to those ideas, the students approved that extensive reading improved their reading skills by providing sufficient exposure.

The sense of enjoyment offered by extensive reading also increased the students' motivation to practice their reading. Based on Hofer's (2011) theory about the indication of motivation, most students agreed that extensive reading encouraged them to read more because they had freedom to choose, and they made effort to complete their reading logs despite their lack of perseverance. Furthermore, the students revealed that they stopped reading right after the course ended although they admitted that extensive reading motivated them to read more. It might occur as every student had different level of intrinsic motivation. Another reason was that the students did not choose the books based on their interests or their reading abilities. Besides improving reading skills and motivating to read more, the students also agreed that extensive reading gave good impact to the students' language skills and components, such as vocabulary, grammar, speaking, and writing as pointed out by Ghanbari and Marzban (2013) in their theory about the advantages of extensive reading. Those skills and components were improved not only through reading extensively but also through making reading logs. As a follow-up activity, reading logs helped the students improve their reading comprehension because the student had to really understand what they had read so that they were able to make summaries. Making reading logs also consolidated what the students had read (Lyutaya, 2011). 
Table 2. The Students' Responses about the Frequency of Feedback from the Lecturer

\begin{tabular}{|c|l|c|}
\hline \multicolumn{1}{|c|}{ Items } & \multicolumn{1}{|c|}{ Responses } & $\begin{array}{c}\text { Total of } \\
\text { Respondents }\end{array}$ \\
\hline \multirow{2}{*}{$\begin{array}{l}\text { My lecturer... gave me } \\
\text { some feedback about my } \\
\text { reading logs. (frequency) }\end{array}$} & sometimes & $\begin{array}{c}12 \\
\text { always }\end{array}$ \\
\cline { 2 - 3 } & never & $11 \%)$ \\
\cline { 2 - 3 } & & $(38 \%)$ \\
\hline
\end{tabular}

Table 3. The Students' Responses about the Usefulness of Feedback from the Lecturer

\begin{tabular}{|c|c|c|}
\hline Items & Responses & $\begin{array}{c}\text { Total of } \\
\text { Respondents }\end{array}$ \\
\hline \multirow{3}{*}{$\begin{array}{l}\text { I think feedback or } \\
\text { comments given in my } \\
\text { reading logs by the } \\
\text { lecturer were ... for me. } \\
\text { (usefulness) }\end{array}$} & useful & $\begin{array}{c}24 \\
(83 \%)\end{array}$ \\
\hline & no answer & $\begin{array}{c}3 \\
(10 \%)\end{array}$ \\
\hline & not useful & $\begin{array}{c}2 \\
(7 \%)\end{array}$ \\
\hline
\end{tabular}

Even though Mikeladze (2014) proposes that supervising the students' progress and giving the students some feedback for their reading logs are the lecturers' or teachers' roles in extensive reading activity, the lecturer admitted during the interview section that she rarely gave the students feedback and had little time monitoring the students' progress and assignments. She said that it happened as she was demanded to finish the syllabus rather than to focus on supplementary activity like extensive 
reading. The lecturer's statements were supported by the students' responses to a question in open-ended section. Most students stated that the lecturer sometimes gave them feedback, and a few of them even dared to say that the lecturer never gave them any feedback. On the other hand, the students realized the importance of feedback from the lecturer as well as the lecturer herself. In short, the lecturer had not fulfilled the students' needs in terms of guidance.

\section{Conclusion and Suggestions}

Extensive reading activity has been carried out by the English Department to improve the students reading skills and language proficiency. In response to the program, this study was conducted to find out the students' perception on extensive reading activity in Reading A course. The main respondents of this study were the students who attended Reading A in the academic year of 2017/2018. To express their perception on extensive reading activity, the students filled in the questionnaire which were constructed based on the theories, other researches about extensive reading, and the real situation in the classroom. The interview with the lecturer of the course was also conducted to confirm the students' responses in the questionnaire. The survey results revealed that the students' perception on the activity was quite positive even though they admitted that they sometimes did not conduct the activity seriously and that the lecturer did not give them feedback regularly. Similar to the students' responses, the lecturer also stated that extensive reading activity was supposed to be an effective method to improve the students' reading skills. However, she revealed that the students did not do the activity correctly and seriously, and it made her discouraged to give some constructing comments for her students. Furthermore, she was not able to give any feedback because she had to handle some other classes and because she lacked time in guiding the students. 
Regarding the results of the study, it will be better for the English Department to assign the assistants of EDR2 laboratory to help the lecturers conduct the activity. Consequently, the English Department should have certain criteria to recruit the assistants. The other alternative is that the English Department has to make sure that every classroom has one lecturer. Another suggestion is that the English Department can add oral examination besides reading $\log$ as the follow-up activity of extensive reading. The examination is aimed to ensure that the students really conduct extensive reading activity and write the reading logs themselves. Besides, it can make the students more seriously because they are afraid of getting bad scores in the examination. During the examination, the English Department can have other lecturers test the students in order to obtain objective assessment. Besides the English Department, the lecturer also needs to participate in improving the activity by monitoring the students better and giving them more feedback. Furthermore, the lecturer may set the limitation of the options. There may be some titles of novels provided for the students to choose, and it has to be ensured that the lecturer knows about those stories. Besides avoiding the students to get confused, it can help the lecturer to give suitable feedback and assess the students in the oral examination. Another suggestion is that the lecturers can change the material for the activity. Instead of asking the students to read novels or compilations of short stories, the lecturers may lead the students to read news items or article with topics which are appealing for the students. By doing that, the students are expected to get more motivated besides gaining important information. The last suggestions are offered to the next researchers. The next researchers who are interested in extensive reading have broader opportunities in figuring extensive reading in other aspects. Some recommended aspects include extensive reading from the lecturer's point of view, other implementation of extensive reading besides making reading logs, or even figuring out the differences of the students' reading skills before and after doing extensive reading. 


\section{References}

Alderson, J.C. (2000). Assessing Reading. Cambridge: Cambridge University Press.

Alexander, J. E. \& Filler, R. C. (1975). Measures of Reading Attitudes. Elementary English, 52(3), 376-378. Retrieved on September 6, 2018, from National Council of Teachers of English, https://www.jstor.org/stable/41592628.

Aliponga, J. (2013). Reading Journal: Its Benefits for Extensive Reading. International Journal of Humanities and Social Science,3(12), 7379. Retrieved from http://www.ijhssnet.com.

Atilgan, A.B. (2013). Effects of Extensive Reading on Writing in Terms of Vocabulary.INTESOL Journal, 10(1), 53-63. Retrieved from https://journals.iupui.edu/index.php/intesol/index.

Bamford, J. \& Day, R.R. (1997). Extensive Reading: What Is It? Why Bother?. TLT Online Editor. Retrieved from http://www.jaltpublications.org/tlt/files/97/may/extensive.html.

De Morgado, N. F. (2009). Extensive Reading: Students' Performance and Perception. The Reading Matrix 9(1), 31-43. Retrieved on December 13, 2018, from https://www.researchgate.net/publication/253319496.

Démuth, Andrej. (2013). Perception Theories. Retrieved on April 28, 2019, from

https://www.researchgate.net/publication/310832124_Perception Theories

El-Hindi, A.E. (1997) Connecting Reading and Writing College Learners' Metacognitive Awareness. Journal of Developmental Education 21(2), 10-12, 14, 16, 18. Retrieved on May 3, 2018, from National Center for Developmental Education, http://www.jstor.org/stable/42775722. 
Essays, UK. (November 2018). Theories of Perception. Retrieved from https://www.ukessays.com/essays/psychology/theoriesperception-2618.php?vref=1

Ghanbari, M.\& Marzban, A. (2013). Effect of Extensive Reading on Incidental Vocabulary Retention. Procedia-Social and Behavioral Sciences, 116(2014), 3854-3858. Retrieved from http://www.sciencedirect.com.

Gibson, E.J. \& Levin, H. (1975). The Psychology of Reading. Cambridge: The MIT Press.

Hann, F. (2018). The Effect of Choice on Reading Anxiety, Reading Autonomy, Reading Interest, Reading Self-Efficacy, and Reading Performance (Doctoral dissertation). Retrieved from ProQuest Dissertations and Theses database. (ProQuest No. 10784436).

Hausheer, H. (1928). A Theory of Perception. The Journal of Philosophy, 25(24), 645-651. Retrieved on May 3, 2018, from Journal of Philosophy, Inc., http://www.jstor.org/stable/2014608.

Hofer, B. (2011). Motivation in the College Classroom. (Svinicki, M. \& McKeachie, W. J., Ed.) McKeachie's Teaching Tips. Belmont: Wadsworth.

Huang. Y. C. (2015). Why Don't They Do It? A Study on the Implementation of Extensive Reading in Taiwan. Cogent Education, 2(1), 1099187. Retrieved on December 21, 2018, from https://doi.org/10/1080/2331186X.2015.1099187.

Hunt, J. R. (2014). Extensive Reading in English in Hitotsubashi University PACE Classes: Justification, Establishment, and Objectives. Hitotsubashi Journal of Commerce and Management, 48(1), 4353. Retrieved on May 3, 2018, from JSTOR, http://www.jstor.org/stable/43295051. 
Lee, H. N. \& Mallinder, M. (2017). Role of Extensive Reading in EFL Vocabulary Development: Review and Recommendation. The English Teacher, XL, 145-163. Retrieved from https://journals.melta.org.

Lyutaya, T. (2011). Reading Logs: Integrating Extensive Reading with Writing Tasks. English Teaching Forum 49(1), 26-34. Retrieved on May 8, 2019, from ERIC, https://eric.ed.gov/EJ936092.

Mikeladze, T. (2014). Extensive Reading. Retrieved on April 27, 2019, from https://www.researchgate.net

Mikulecky, B.S. (2008). Teaching Reading in a Second Language. Retrieved from https://www.longmanhomeusa.com.

Neufeld, K. (1975). A Kaleidoscopic Reading Organization Plan. Elementary English, 52(5), 673-675. Retrieved on May 3, 2018, from National Council of Teachers of English, http://www.jstor.org/stable/41592587.

Pollitt, A. \& Taylor, L. (2008). Cognitive Psychology and Reading Assessment. (Sainsbury, M., Harrison, C., \& Watts, A.) Assessing Reading from Theories to Classrooms. Retrieved on May 8, 2019, from www.nfer.ac.uk.

Rankin, J. (2005). Easy Reader: A Case Study of Embedded Extensive Reading in Intermediate German L2. Die Unterrichtspraxis / Teaching German, 38(2), 128. Retrieved on September 6, 2018, from Wiley on behalf of the American Association of Teachers of German, https://www.jstor.org/stable/20060000.

Takase, A. (2012). The Impact of Extensive Reading on Reluctant Japanese EFL Learners. The European Journal of Applied Linguistics and TEFL, 1, 97-113. Retrieved on September 6, 2018, from http://www.theeuropeanjournal.eu/. 
Tip Sheet on Question Wording. (2007). Retrieved on December 13, 2018, from Program on Survey Research of Harvard University, https://psr.iq.harvard.edu.

Touhid, T. (2015). Analyzing Implementation of Extensive Reading in ESL Classrooms (Bachelor's thesis). BRAC University, Dhaka, Bangladesh. Retrieved on December 21, 2018, from https://dspace.bracu.ac.bd.

Ushenko, A. (1940). A Theory of Perception. The Journal of Philosophy, 37(6), 141-151. Retrieved May 3, 2018, from Journal of Philosophy, Inc., http://www.jstor.org/stable/2018782. 